\begin{tabular}{|l|l|l||}
\hline \multicolumn{2}{|c|}{ PublisherInfo } \\
\hline \hline PublisherName & $:$ & BioMed Central \\
\hline \hline PublisherLocation & $:$ & London \\
\hline \hline PublisherImprintName & $:$ & BioMed Central \\
\hline \hline
\end{tabular}

\title{
Fly SNPs
}

\begin{tabular}{|l|l|l||}
\hline \multicolumn{2}{|c|}{ ArticleInfo } \\
\hline \hline ArticleID & $:$ & 4257 \\
\hline \hline ArticleDOI & $:$ & $10.1186 /$ gb-spotlight-20011121-01 \\
\hline \hline ArticleCitationID & $:$ & spotlight-20011121-01 \\
\hline \hline ArticleSequenceNumber & $:$ & 328 \\
\hline \hline ArticleCategory & $:$ & Research news \\
\hline \hline ArticleFirstPage & $:$ & 1 \\
\hline \hline ArticleLastPage & $:$ & 2 \\
\hline \hline & & RegistrationDate : 2001-11-21 \\
ArticleHistory & $:$ & OnlineDate $\quad$ 2001-11-21 \\
\hline \hline ArticleCopyright & $:$ & BioMed Central Ltd2001 \\
\hline \hline ArticleGrants & $:$ & \\
\hline \hline ArticleContext & $:$ & 130592211 \\
\hline \hline
\end{tabular}




\section{Jonathan B Weitzman}

Email: jonathanweitzman@hotmail.com

The availability of a dense map of sequence polymorphisms is invaluable to speeding-up the mapping of mutations linked to phenotypes or disease. In the Advanced Online Publication issue of Nature Genetics, Jurg Berger and colleagues from Research Institute of Molecular Pathology in Vienna report the identification of 7,223 single nucleotide polymorphisms (SNPs) and 1,392 insertions/deletions (indels) in laboratory strains of Drosophila (DOI:10.1038/ng773). They used a directed strategy involving the amplification and sequencing of short sequences from two strains, and found a sequence polymorphism every 150-200 bp and many constitute restriction site polymorphisms (RFLP-SNPs). The SNP map of the Drosophila genome generated by Berger et al. will allow rapid and accurate mapping of many fly mutations.

\section{References}

1. A rapid method to map mutations in Drosophila.

2. Nature Genetics, [http://genetics.nature.com]

3. Research Institute of Molecular Pathology , [http://www.imp.univie.ac.at] 